\title{
Staging the Authentic and the Theatre of Universality in J.M. Synge's The Shadow of the Glen
}

\section{Didachos Mbeng Afuh}

The Department of English, Faculty of Arts Letters and Social Sciences, University of Ngaoundere, Ngaoundere, Cameroon

\author{
Email address: \\ afuhmbeng.junior@yahoo.com
}

\section{To cite this article:}

Didachos Mbeng Afuh. Staging the Authentic and the Theatre of Universality in J.M. Synge's The Shadow of the Glen. English Language, Literature \& Culture. Vol. 5, No. 4, 2020, pp. 132-138. doi: 10.11648/j.ellc.20200504.12

Received: July 21, 2020; Accepted: August 3, 2020; Published: December 8, 2020

\begin{abstract}
This paper argues that J.M. Synge's [1] The Shadow of the Glen can be used to sharpen our understanding of the relationships between regionalism, universality and the authentic in dramatic literature. My suggestion is that the key component in that tension is Synge's presentation of what was to be considered authentic, since literature in Ireland was real exercise in fostering national consciousness. I argue that Synge's representation of the regional drifts from issues of "authenticity" not because it is not a factual account of real events, but because it is not so heavily and so self-consciously authenticated. As shall be argued below, The Shadow of the Glen is concerned with the local, presented with a universal interest. Synge universalizes the characters' experiences as he revisits the golden past of the Gaelic culture. This is not to suggest that the playwright was not authentic, but instead that his play shows the author's self-awareness about how literary constructions of the authentic function. He understood that the representation of the regional to a metropolitan audience will always require a negotiation of the relationship between reality and audience's expectation. Synge managed that tension not by asserting the authenticity of his narrative but by insisting on the authenticity of his own outlook as an artist. This selfconsciousness in the presentation and reconstruction of the clash between the regional and the global is an example of how we can think of Synge as a modernist writer.
\end{abstract}

Keywords: Authenticity, Universality, Local Colour, Irish Peasantry, Irish Myths, Revivalist

\section{Introduction}

J.M. Synge's plays did not receive a positive responds from critics and theatregoers as much effort had been to defend the view that he was an Anglo-Irish who set out to thwart the efforts of the revivalist, and therefore misrepresent Ireland. Commenting on the fact that Synge's drama got the fair treatment from the audience during their early performances, Arthur Clery describes his plays as "decadent", "corrupt", "cynical", and, worst of all, "no more Irish than the Decameron" [qtd in Grene and Shaun [2, pp. 31]. They conclude that Synge exaggerated the filth, poverty, immorality and alcoholic nature of the Irish Peasantry. Grene and Richards in this respect insist that the objection to his plays was not just moral as "his plays made fun of the Irish Peasantry in a way that was not significantly different from the British description of an Irish" [2, pp. 45]. Robin Skelto feels that the dubious morality of Synge's characters is unIrish and so accuses him of placing an essentially alien story in an Irish context and thus falsifying the picture of rural Ireland [qtd in Nozen 3, pp. 89].

The above mentioned critics and many more overlook Synge's dramatic realism and the stylistic diversity of his works. Their criticism therefore lead to a neglect of the significance of his plays towards the fight for Irish home rule. This limited approach can be particularly harmful for the reconstruction of various aspects of Synge's realism especially if we consider their criticism as pointing to the fact that Synge was not authentic in his presentation of Ireland.

Before I continue, it is important to establish a working definition of authenticity, regionalism and the universal. One way of speaking about the authenticity of a work of art is to confirm its provenance by stating verifiable evidence that the composition is undoubtedly the work of the artist who claims to have created it. Another way of looking at authenticity, and this is my working definition, is when we have in mind something close to the notion of being true to oneself. In this case, what we demand of a work of art "...is a subjective experience that either enables us to feel more attuned to our 
real selves" [Guignon 4, pp. 15], or that represents the world to us in such a way as to persuade us that the artwork is not just realistic but also "pure" and less mediated. This form of literature is best served as a prominent tool in the spread of the spirit of nationalism.

Skelton considers the regional as "a compendium of folk beliefs, colours, clothing, landscape, the sea, certain actions and utterances and the hearth, and all have superstitious meanings" [qtd in Kiberd 5, pp. 336]. Kiberd [5] mentions Irish folklore and local human life that drama must not allow to die down. For example, "in raking the fire aimlessly, Maurya gives us a vital clue to the Irish spiritual condition, a phenomenon which will soon be overtaken" [5, pp. 16]. Such writings, according to W. B. Yeats [6] will be of a greater service to [their] country and this should not compromise the service of a course. This local colour or regional literature focuses on characters, dialect, customs, topography and other features particular to specific regions. The idea is to target the dual influence of romanticism and realism, since the author draws from ordinary life of distant lands, exotic scenes, and retains life through minute details with a sense of fidelity and accuracy of description.

The notion of universality is based on the assumption that there are "irreducible features of human life and experiences that exist beyond the constitutive effects of local cultural conditions" [Ashcroft 7, pp. 51]. This can be traced in the universal human being in Western humanist movement. Universalism offers a hegemonic view of existence by which the experiences, values and expectations of a dominant culture are held to be true for all humanity.

This unicentric and universal orientation made Synge to transform a colonial reality into a world's intellectual, economic and political affair, with Ireland at the center. In The Shadow of the Glen, Synge [1] gives Irish local realities a universal touch. In a dialectical fashion the playwright represents a society's behavoural patterns and shapes or alters that culture's dominant code.

Louise Montrose [8] insists that the aim of new historicism [the perspective which this study is conducted] is to redefine the relationship between a text and the cultural system in which they were produced. In a much quoted phrase, he describes new historicism as a "reciprocal concern with historicity of text and the textuality of history" [Wiedenmann 9, pp. 91]. This is to say history is conceived not to be a fix objective facts, but like literature with which it interacts, a text that needs to be interpreted. The effect of such unity heightens the text's sense of design, hence its authenticity. In The Shadow of the Glen, everything takes a meaning: the cottage, the landscape and the past and present reflect the local culture, yet truly transcending the natural regional order, and are realistic explanations of happenings in 19th century Europe.

\section{Synge as an Agent for the Cosmopolitan Space}

The association between Synge and regionalism probably owes much to W. B. Yeats as expressed in the preface Yeats wrote to Synge's 1905 play The Well of the Saints, in which he claimed to have changed Synge's destiny by asking him to go west:

Give up Paris, you will never create anything by reading Racine, and Arthur Symons will always be a better critic of French literature. Go to the Aran Islands. Live there as if you were one of the people themselves; express a life that has never found expression. [6, pp. 68]

The turn away from metropolitan literary sources to direct inspiration from the lives of the Irish people was a key concept for those writers seeking to create a new Irish national literature at the end of the nineteenth century. Synge, who did travel to the rocky islands in the mouth of Galway Bay in May 1898 and who, in the four annual visits there in successive years [Rayburn 10, pp. 20], found the material from which he was to create many of his plays, was the perfect illustration of the principle. He was in many respects a recruit to the movement.

What is interesting in Yeats' declaration above is how he positions Synge in relation to the people of the Aran Islands. Synge should live not as one of the people, but as if he were one of them, wrote Yeats [6] - who then cast Synge not as an artist but as an agent: as someone who will give voice to what is already there. There is therefore a fascinating tension between the real and the artificial in Yeats's lines: Synge's role is to act as if he is something that he is not - but through that performance he will reveal and express an underlying truth. Synge's task, as conceived by Yeats was to retrieve something original from the regions and to convey it in a form that can be understood in metropolitan and cosmopolitan literary centers.

But it was the simplicity of the life there and its difference from the familiar urban worlds of Dublin or Paris which evidently held Synge's imagination. Christopher Collins [11] writes that Synge "... had always been a lover of the natural world, and the sheer struggle for existence of those who had to survive in the barest of rocky environments appeared to him a vivid metaphor for the human condition itself" [pp. 2]. This is what he found decent to present to the world. He used the Aran realities to impact a much greater audience. Although Aran inspired Synge with the 'shock of the new', he had early been familiar with the mountainous terrain of County Wicklow on the east coast south of Dublin where his ancestors were long established landowners and where he with his mother had spent many extended family holidays [Fogarty 12, pp. 22]. Wicklow was to prove the setting for his plays, not as an agent but as an artist who is answerable to the world and not to Yeats. He might have gone there as a recruited member of the new national theatre, but his contact with the primitive society and with the natural world plunged him into new thoughts that must be given life the way he as an artist perceives it. He saw in this myth of primitive society a construct that reflects his own desires for a more simplistic and modern mode of existence.

The part of Aran life that Synge seeks to present is a selfprojection that, in the words of Geoffrey Rayburn "has little 
to do with the 'realities' of savage existence" [10, pp. 3] that Yeats and his colleagues wanted him to project, and all have to do with Synge's imagination. Regionalism therefore becomes the forum through which the playwright reorganizes a people to fit personal and political paradigms that are useful to the universal. In this case, regionalism becomes a naïve and perhaps beautiful process of nostalgia, and cannot be seen as a subordination of the Other to what ends history continues to demonstrate. It ceases to be the idealization of the primitive [Yeats' consideration]; a process that is more reflective of the person or society doing the idealizing than it is of the people or culture being idealized. Within this context, and within the context of Ireland, Synge's regionalism concentrates on the peasants who populate the West of Ireland, the Aran peasantry - the islanders -with a long-standing romantic perception to present the hierarchical structure of the outside larger society, and to subvert the values he finds there, values that are not particular to Aran peasantry.

\section{The Irish Legend and the Universal Purpose in the Shadow of the Glen}

J.M. Synge wrote when glorifying the Irish material as a way of cultural resistance against the English colonial and literary hegemony was the prescribed mode. What made him one of the distinctive Irish writers in the Irish dramatic movement was his ability to use the Irish habitat to strengthen national feelings, and at the same time establish a distinct new Irish identity that will usher them into the modern world. In this light, as Synge himself puts it, a "...writer's first duty to his country is disloyalty" [qtd. in Ashcroft 7, pp. 174]. By disloyalty, he means the responsibility of not presenting Ireland the way the people want it presented, but by handling the Irish myths and traditions in the way that will move society forward. Synge was cultural and nationalist-conscious the same way he was time and universally-haunted when he wrote The Shadow of the Glen, and his characters represent this double standard.

The Shadow of the Glen was developed from a story told to Synge by Pat Dirane, the old and shanachie of Inishmaan, in 1898. In responds to an accusation for falsifying the picture of rural Ireland, Synge wrote: "Sir, I beg to enclose the story of an unfaithful wife which was told me by an old man on the middle island of Aran in 1898, and which I have since used in a modified form in The Shadow of the Glen" [qtd in Kumar 13, pp. 92]. In this story, the shanachie narrates how, on a rainy night, while travelling from Galway to Dublin, he came across a house in which a solitary woman sat watching a man laid out in a bed as if he were dead. The woman gave the shanachie shelter and asked him to watch by the corpse while she went out to tell her friends of the death. When the woman had gone, the "corpse" sat up and told the shanachie, "I've got a bad wife so I let on to be dead to catch her at her goings on". The woman returned to the cottage with a young man whom she sent into the bedroom to rest. In a little while she joined the young man in the bedroom. The husband waited for a few moments and then got out of bed and took up a stick and gave the shanachie another, and both men went into the bedroom, and when they saw the wife and her companion together the husband "hit the young man with the stick so that his blood lept up and hit the gallery".

Eilis Ni Dhuibhne [14] demonstrates in her essay that the story Pat tells is quite common in Irish folklore and that versions of it have been collected throughout Ireland. Geoffrey Rayburn on his part exploits elements in the story as acts of testing its credibility. He identifies the credibility of the story by considering the fact that the storyteller claims to have been the witness of the events he recounts, the location of the story, the narrator's reference to material objects: the cottage, the candles, the blackthorn sticks, the whiskey and bread, some of which appear irrelevant. The fact that Pat's story was immediately challenged also adds to the credibility of the story. Synge writes that when Pat finished the story, he found himself entering into a "moral dispute" with one of his listeners - perhaps one of the nursing women, perhaps someone else. Synge could not follow the debate because it was being conducted in Irish at a very fast pace - which implies that the dispute was heated. And it was a dispute, furthermore, that "caused immense delight to some young men who had [also] come to listen to his story," writes Synge in The Aran Island.

Synge draws material for his play from the life of the peasants in the Aran Islands and eastern Ireland. His work therefore immortalizes a lifestyle of a disappearing Gaelic culture. As an artist he believes every life is a symphony, and the translation of this life into simple music, and from music back to literature is the real effort of the artist. He does translate the hard primitive peasantry Irish life into literature, and brings to the audience's mind the glory of the Irish peasantry, their hopes, dreams, despairs and joys by means of the language of their daily lives, and gives this life a universal dimension.

In The Shadow of the Glen, Synge treats Irish life, thus giving his play a local quality. His visits to the Aran Islands and his interaction with the islanders provided him with the raw material for this purpose, what Christopher Collins calls "cottage kitchen realism" [11, pp. 13]. By so doing, Synge shared with Yeats his interest in the Gaelic imagination. The rural setting and characters in The Shadow of the Glen enable us to see facets of the psychological and spiritual predicaments not only of rural Ireland, but of Europe at large. The pasture-dependent country folk of Aran, the land-locked peasantry of the Wicklow glens, and the survey of tramps, the "travelling people" who have abandoned all claims to stationary property, but who are still affected by the pressures of conventional attitudes and bewildered by the conflict between two traditions, the mounting tide of rebellion, the Christian ethos and religious beliefs, moral standards, and conventional social attitudes are tackled with increasing universal vigour.

The rural and regional landscape and the cattle and goats on it constitutes an essential symbol in The Shadow of the 
Glen. Mathews writes that "In Synge's one act play, nothing is made prominent but the landscape [15, pp. 64]. Synge first makes reference to the landscape and the calmness of the whether to indicate that Nara Burke goes to it to wave the boredom created by Dan's constant absence. As Nora explains to the tramp, it is a life in which

you do be sitting, looking out from a door ... seeing nothing but the mists rolling down the bog, the mists again, and they rolling up the bog, and hearing nothing but the wind crying out in the bits of broken trees were left from the great storm, and the streams roaring with the rain.[1, pp. 4]

Here, Synge presents the natural and local landscape as a force and a mystery capable of relieving and consoling the battered. The roaring streams, the crying wind and the rolling midst combine to produce an elating sound while the broken trees from the great storms reinforce the local Irish colour.

Towards the end of the play, the Tramp invites Nora to come with him to nature where she will "be hearing the herons crying out over the black lakes, and the grouse, and the owls with them, and the larks and the big thrushes when the days are warm" [1, pp. 17]. In their new environment, "there'll be no old fellow wheezing the like of a sick sheep close to [her] ear. Many commentators on Synge have interpreted the ample time and space accorded to the local landscape as his desire to return to the elementary human values. In Fogarty's opinion, it is the playwright's "reexamination of the basic human drives and instincts in order to confirm their absolute validity and necessity for human growth and development" [12, pp. 236]. Synge's role as an artist was not only to capture this "golden age" where men lived in total harmony with the organic world but to show how through it man can see how his zestful desire of life's pleasures can drive their own very insistence through the mud.

While immortalizing a Gaelic culture, Synge's artistic creation in The Shadow of the Glen becomes the paradigm mode in which people round the world could come to selfdefinition. The play was released to the public when there was a need for a drastic cultural and social change. Synge purposefully wrote illustrating the socio-cultural atmosphere as becoming increasingly popular. As outlined by new historicism literary theory, there is a dynamic web of discourse within the culture of a producing event and the culture of the interpreting event. Synge aligns with modernity and modernism to break with their predecessor romanticism. Freedom, or libertinism, was the real big issue of the modern times: freedom from the Church and its clerics, freedom from the landlords and feudalism, freedom of the individual.

Through Nora Burke and Dan Burke, Synge depicts the unhealthy relationship between husbands and wives in his native Ireland, and in Europe in general. In this relationship, Synge saw a repeat of the relationship between the colonizer England and the colonized Ireland. The torture, repression, oppression and other forms of injustice that Ireland suffered in the hands of Britain is represented in this family drama through Dan Burke and his wife. To make this argument clearer, Synge introduces a tramp who constantly refers to Nora as "lady of the house" and Dan as "master of the house". The lady and master relationship is symbolic of colonizer/colonized relationship. Synge therefore evokes a particular Irish reality at the time he was writing [Irish colonized position] while at the same time adding his voice to the woman question which was already popular in his nineteenth century European society.

Dan Burke meticulously gives details on how the house should be run so that Nora remains economically and political dependent to him. He owns the money on the table and the sheep on the hills, and Nora is like the intruder. She does not go out, she should not whistle and is expected to take every of Dan's orders. Nora is also supposed to accept in good faith curses inflicted on her by Dan. Dan is evil and does not trust his wife. That he fakes death is something out of the human realm. Nora observes that Dan, even when "alive" "was always queer, stranger and I [she] suppose them that's queer and they living men will be queer bodies after." And later she declares: "I was afraid, stranger, for he put a black curse on me this morning if I'ld touch the body the time he'ld die" [1, pp. 3]. Nora has been living with a husband who curses instead of blessing her. His queer and inhuman nature gives him the mind to fake death. Despite the evidence that suggests to Nora that her husband might not be dead, she refuses to think in that direction because such a thing is not common. Nora has lived a cheerless life under the tyrant, "always thinking thoughts in the dark midst" [1, pp. 4].

Apart from making life uncomfortable for Nora through his rules and curses, Dan is also unfriendly [cold] thereby imposing a very boring marriage life on Nora. While asking the tramp to touch the "body" on the bed to confirm if it is dead, Nora recalls that Dan has always been cold while "alive" and says "maybe cold would be no sign of death with the likes of him, for he was always cold, every morning and every night" [1, pp. 5]. Nora's declaration that her "dead" husband was always cold can be subjected to the interpretation that he was inactive in bed, and that is why no child is mentioned in the play. Nora therefore suffered sexual starvation, reason why immediately she realizes that Dan is "dead" she runs out for Michael, hoping to put an end to the long nights of Dan's "coldness". He would not interact with her during the day thereby offering her a lonely conjugal life. "Cold" in this situation can also be associated with death. To Nora therefore, Dan was dead even when he thought he was alive. It has therefore been traumatizing to her living with a "dead man". In such a situation, isolation and a sense of not belonging become intense. Little wonder that Nora is to live without a child, an indication that Dan is not only cold and queer but also impotent and thus cannot provide her with the happiness she deserves. In this relation, Synge draws the people's attention to the loveless marriages that ran through Ireland's cosmopolitan and metropolitan settings in particular, and through Europe as well, with the message that freedom begins at home. 
Nineteenth century Ireland [Europe] saw a situation where women's contributions to the economy were limited, and men enjoyed their status of all powerful and all having. Robert Kennedy writes that "[Irish] men took care of the fields and the animals, while women were responsible for the usual duties of cooking, housework, and child care [qtd in Rayburn 10, pp. 54]. To Synge, the liberation of Ireland was to start with the liberation of the woman. No doubt he presents in Nora Burke a personality filled with profound hunger for liberty. Ghafourinia and Baradaran [16] in comparing Nora Helmer in Ibsen's A Doll's House and Nora Burke write that Ibsen's Nora is a true liberal who takes her destiny into her own hand by slamming the door, while Nora Burke is a conformist who waits for her husband to throw her out. Contrary to what they think, Nora Burke, just like Nora Helmer, chooses to leave. She has not been caught redhanded by her husband as Synge offers no evidence of such a suggestion. Dan's act of asking her to leave could be seriously resisted if she wanted to. But she decides to leave because her leaving the marriage fits her will and desire. In effect, she decides to leave because she is no longer docile. Her decision to follow the tramp has already been made even before Dan asks her to leave; we noted her conscious reference to nature, her new environment, each time she spoke. Though her leaving the cottage is not as dramatic as Nora Helmer's, her decision to leave is personal and not forced, and it is a sign of her emancipation over repressive conservative systems.

Another nineteenth century social ill which was part of the Irish native but not particular to them, and which Synge brought to the attention of the audience was excessive drinking. Mary Burke [17] reports that the consumption patterns of commodities such as alcohol and tobacco were integral part of Irish social life, and this took place in pubs or shebeens because the structure of Irish villages and towns, with their crowded and inadequate housing and scarcity of recreational facilities, provided conditions in which shebeen or drinking places could become the central socialising influence for adults. In this light, and this brings out the universal in the nineteenth century drinking pattern, Declan Kiberd relates that "The British soldiers in Ireland [during the colonial period] provided ready markets for both foreign and locally brewed drinks... and Irish prostitutes" [5, pp. 17].

The stage direction at the beginning of The Shadow of the Glen suggests that Dan has not only been heavily drinking, but has also been running after prostitutes. Dan is heavily alcoholic in nature as "there are a couple of glasses on the table and a bottle of whisky as if for a wake" [1, pp. 1]. At first thought, the couple of glasses suggest he has company. But a further reading shows how alcoholic he is. The scene suggests that Dan has been drinking before deciding to fake death. He is addicted to alcohol and his insatiable thirst for it is seen when while in bed, pretending to be dead, he orders the tramp to serve him a glass of whisky when Nora is out. We laugh because the dead do not drink. But as we laugh, we are forced to ponder over Nora's predicament. She has lived all her life fighting the stench of alcohol with the person she shares her bed. Dan's addiction would not allow him even finish the game of death he is playing. The moment Nora is out of sight, he immediately asks for a glass of whisky. Had Nora stayed a little longer, his game would have ended prematurely because he would have asked for a glass as well. His love for alcohol indicates that certain decisions are taken under the influence of it. And this is Synge's point: the alcoholic cannot think right, and as such cannot strategise properly in the fight for home rule. The Irish needed to abandon such habits and face the realities of their liberation process. Lionel Trilling thinks that "for a writing to be considered authentic, it must, create a vision of life that is separate from social convention, and which seems different from mass-produced culture" [qtd in Kitishat 18, pp. 83].

As a modern Irish playwright who sought universal recognition, Synge thought that limiting himself to what was known as the revivalist agenda, was destructive both to himself as an artist, and to the Irish people who sought political and spiritual liberation from Britain and from the Catholic Church. Capturing the capitalist spirit of his time was therefore inevitable. Al - Ghoreibi [19] writes that at the end of the nineteenth century, Western theatre was in the perfect position to explore the ambiguous impact of capitalist culture (2). This means that any serious drama of the day could not entirely purge itself of the tarnish of commerce. In The Shadow of the Glen, Synge took it a duty to heighten its awareness and contradictions through characters like Dan Burke and Michael. Through local farming of land, goats, and cattle rearing Synge presents the importance Europe and the world gave [still gives] to the market economy and money and wealth.

We first see Michael when he comes in with Nora when Dan is pretending to be dead. At this moment, Nora is in a serious state of trauma. Instead of playing the role of a comforter, the first thing he does is to assess the money and wealth that has been left behind:

Nora: what way would I live and I am an old woman with a bit of farm, and cows on it, and sheep on the back hills.

Michael: [considering] That's true, Nora, and maybe it's no fool you were, for there is good grazing on it... and I am thinking it's a good sum he's left behind. [6] Michael makes his intentions clear. He associates with Nora not because he wants to console an aging widow and save her from eventual loneliness, but because he wants to marry her so as to be in control of Dan's property. Nora's response to him is even more assuring especially when she explains to him that she made a mistake to have married Dan for his wealth. Michael is doubly assured that he would not have to fight over the property with anybody. In Nora's words, the property is "a bit of a farm with cows on it, and sheep on the back hill" [6]. From this revelation, Michael is confident that his preying tactics are sailing through especially now that Nora is vulnerable. He therefore prepares to assume full ownership over what "the dead man" has left behind.

Nora's decision to marry Dan was selfish. She married Dan out of a desire for material wealth and not for love, and later realized that the former could not bring her comfort and 
life's fulfillment. What she needs now is emotional freedom; an arena where she can easily and freely express herself, where she can be loved and be respected. But Nora is not in any good hands for Dara Michael is too materialistic to love back and so cannot offer Nora what she desires. When Nora releases the money she has inherited from her "dead" husband, Michael says: "That's five pounds and ten notes, a good sum" [1, pp. 7]. Happy and excited, he immediately proposes marriage as he makes plans to manage Dan's wealth. He "will bring the sheep up on the bit of the hill" and won't have anything to be worried about when the midst is down [1, pp. 7]. He becomes the master planner over someone else's property. His marriage proposal does not carry with it promises to love and protect Nora. He rather promises to be a good manager of the inherited wealth.

At this point, Nora realizes that she is moving from one oppressor to another. She realizes that Michael is only taking advantage of her vulnerability in order to possess andominate her. In Michael, she sees a resurfacing Dan's queer and exploitative nature. There is therefore no guarantee that the brutality that accompanied Dan's colonial leadership, which she is struggling to liberate herself from, will not resurface. But just when Michael thinks he is in control of the situation, Dan sneezes and sends Nora out of the cottage with nothing. The tramp expects that Michael would go with her. He cannot marry Nora now that she is left with nothing. His decision not to follow Nora is directly linked to the fact that she has no property on which he can rely. Michael's selfish and materialistic nature mirrors the capitalist spirit of Synge's time, a spirit that was gradually creeping into Ireland.

\section{Conclusion}

Synge's international reputation grew rapidly with renowned writers like Vaughan Williams and D. H. Lawrence adapting his plays. His works were translated into other languages as "he had become a landmark figure in Irish theatre, influencing many of later playwrights from Sean O'Casey to Brian Friel, Tom Murphy and Martin McDonagh" [Nozen 3, pp. 16]. This is because he regarded the basic facts related to the Gaelic culture and the islanders' lives as the elemental facts of human existence. He put simple folk on the stage in a realistic manner hitherto unexpressed and unuttered, thus contributing to the development of peasant drama that would serve as the backbone of the modern Irish dramatic movement, and is a genre that continues to influence Irish dramaturgy today.

By giving the classical folk-tale of the Widow of Ephesus a universal touch, and by presenting the mystery inherent in the natural and local Irish landscape, Synge brought the rich Irish past closer to the world and the world closer to Ireland. The dubious morality in his characters should not be taken as an excuse to describe him as being unIrish and as one who falsifies the picture of rural Ireland. Rather, through it, Synge covertly unveils local and universal problems that suffocate, destroy and create in the individual a feeling of insecurity. Synge was therefore involved in nationalistic fight, not as a propagandist or an activist for Yeats agenda but as an artist. His main concern is the peasantry, and through it, he suggests a different perspective than that of the nationalists by pointing out the harsh realities and problems of the era inflicted on the rural community.

\section{References}

[1] Synge, J. M. Collected Works II: Prose. Ed. Alan Price, Gerrards Cross: Colin Smythe, 1982.

[2] Richards, Shaun. Ed. The Cambridge Companion to Twentieth Century Irish Drama. Cambridge: Cambridge University Press, 2004.

[3] Nozen Seyedeh Zahra Amin. A Critical Study of the Contribution of Abbey Theatre to the Promotion of Irish Literature: With Reference to the Selected Works of William Butler Yeats, John Millington Synge and George Bernard Shaw. QUID. Vol. 1, 2017. Price, Alan. Ed. Synge and AngloIrish Drama. London: Macmillan, 2014.

[4] Guignon, Charles. On Being Authentic. London: Routledge, 2004.

[5] Kiberd, Declan. "Synge and the Irish Language." The Cambridge Companion to Synge, Ed. J. P. Mathews. Cambridge University Press, 2009. 333-339.

[6] Yaets, W. B. "J. M. Synge and the Ireland of his Time". Essays and Introductions. New York, Macmillan, 1961. 12-15.

[7] Ashcroft, B., Gareth G. \& Helen T. The Post-Colonial Studies Reader: The Key Concepts. London: Routledge, 2005.

[8] Montrose, Louise. "The Poetics and Politics of Cultures." New Historicism. Ed. Aram Veeser. Oxford: Oxford University Press, 2001. 67-70.

[9] Wiedenmann, S. Heinrich Heine: Dreams in a Winter Tale, A New Historicist Approach. Munich: Grin Verlag, 2007.

[10] Rayburn, Geoffrey. This is Whose Story? A Re-evaluation of John Millington Synge's Primitivism in The Aran Islands. New York: Syracuse, 2010.

[11] Collins, Christopher. Synge and Protestant Comedy: For the Sake of Sanity: Doing Things with Humor in Irish Performance. Cary for Press: Dublin, 2014.

[12] Fogarty, Anne. "Ghostly Intertexts: James Joyce and the Legacy of Synge." Synge and Edwardian Ireland. Eds. Brian Cliff and Nicholas Grene, Oxford: Oxford University Press, 2012. 225-244.

[13] Kumar, Sushil. "The Theme of The Shadow of the Glen". International Multidisciplinary Research Journal, Volume 4, No. 4, 2016. 45-54.

[14] Eilis, Ni Dhuibhne "The Best Field Worker: John Millington Synge and Irish Folklore." Synge and His Influences. Ed. Patrick Lonergan, Dublin: Carysfort Press, 2011. 93-110.

[15] Mathews, J. P. "Re-thinking Synge" The Cambridge Companion to Synge. Ed. J. P. Mathews. Cambridge: Cambridge University Press, 2009. 1-6.

[16] Ghafourinia, Fatemeh, Leila Baradaran. “The Women's Right in Henrik Ibsen's Doll's House" Journal of Novel Applied Sciences. Vol. 3 No. 42014 76-77. 
[17] Burk, Mary. The Riot of Spring: Synge's 'Failed Realism' and the Peasant Drama. Oxford: Oxford University Press, 2016.

[18] Kitishat, Amal Riyadh. "Colonialism and the Recreation of Identity: The Irish Theatre as a Case Study." Journal of Language and Culture. Vol. 3, No. 5, 2012. 83-86.
[19] Al - Ghoreibi, Fathi. "The Troubled Irish Mother Figure in J. M. Synge's Riders to the Sea and Tom Murphy's Bailegangaire." Umm Al -Quora University Journal of Languages and Literature, Vol. 15, No. 1, 2015. 1-13. 